\title{
Discussion on Papers of Drs. Maury, Hardy, Meinecke, Damanski, Tricot and Guttmann
}

Venema, F. B. (Holland) asked whether the solution to the housing problem was to house paraplegics and other very severely handicapped in small communities or was it best to include them in the housing projects of the able-bodied in houses adapted for paraplegics and other severely handicapped people? He personally thought it better to scatter them among the normal population.

Guttmann, L. (England) agreed with Dr. Venema that the ideal domestic resettlement of a paraplegic and indeed any severely disabled person was to live in his own home amongst the community. As far as Great Britain was concerned, they had succeeded in returning most of their paraplegics and tetraplegics to their own homes. As Dr. Hardy had pointed out, there had been great difficulties in adjusting the houses, but in recentyears the housing authorities had become more and more co-operative. It varied of course in the different regions, but he was glad to say that conditions in the North had much improved. There were still some difficulties in the South, particularly in the London area, but by continuous pressure on the part of doctors, welfare officers, etc., conditions were improving gradually.

The second possibility were settlements for paraplegics. These had been built in Great Britain immediately after the war by the Red Cross Society for ex-servicemenone in Watford near London and the other in Macclesfield near Manchester, where paraplegics lived with their families in bungalows. The settlement in Watford catered mainly for paraplegics who were able to take up work in open industry. This was a great advantage and in fact most of the paraplegics were employed in the Watford area. In Macclesfield, Cheshire, the situation was not so favourable, as the factories were very old and access to them difficult. Therefore, the paraplegics there were working under sheltered conditions within the settlement. There were two other homes for ex-servicemen, mainly tetraplegics - one at the Star and Garter Home, Richmond ( 24 beds) and the other at Eastbourne ( 36 beds).

For civilian paraplegics, there were no special settlements. A few lived in Cheshire Homes. There was one large hostel-the Duchess of Gloucester House in London (78 beds) - for those paraplegics, mainly civilians, who were physically able and willing to take up employment in open industry. This hostel was built by the former Ministry of Pensions in co-operation with the Ministry of Labour. It was opened in 1949 and about 350 have since been through this institution. They could live there for as long as they wished, but most stayed there temporarily until they had found accommodation in their own homes. Residents of this hostel were employed within a radius of 12 to 14 miles in factories. The extent to which society in that area had become enlightened by the working capabilities of a paraplegic was shown by the fact that in the small area of Isleworth and Hounslow more than Ioo paraplegics were employed full time in open industry.

All the institutions mentioned were medically supervised by the Stoke Mandeville National Spinal Injuries Centre.

There was, however, a serious problem with regard to domestic resettlement of paraplegics with high lesions, particularly tetraplegics. Although they had succeeded in returning the majority of tetraplegics to their own families one had to consider those who could not return to their own homes. Moreover, as families grew old the problem arose what to do with the paraplegic or tetraplegic. Therefore, a new pilot scheme was about to be started at Stoke Mandeville, within the grounds of Stoke Mandeville Hospital, and he hoped other spinal units would take up the idea. The Ministry of Health had now agreed to a scheme for a hostel of 30 beds for those paraplegics - men and women-who could not live in their own homes. The hostel would be provided with a sheltered work- 
shop, and industry in Aylesbury and surrounding areas would be approached to send work to the hostel for the residents, to make their lives worth living by useful activity.

Finally, Dr. Guttmann said that they must never relax in their efforts to restore paraplegics and even tetraplegics to useful members of society i.e. by work and employment. Kerr, W. G. (Scotland) said that in Scotland there was a Scottish Council for Social Services which was found to be of great use because much of what had been discussed did not apply to paraplegics alone. Dr. Hardy had mentioned housing adaptations and also the problem of financial hardship, and through the Council the Government was being approached on these matters. They had a Secretary of State for Scotland and his departments were tied in parallel with English Ministries, and there was an endeavour to maintain uniformity which often meant that ideas originating in Scotland might not be accepted by the Ministry of Health in England. With regard to housing, there was the very big problem of those who were unfit to go home, and he was very pleased to hear of the steps being taken in Stoke Mandeville for this type of hostel. He thought that if paraplegics were scattered all over Britain, particularly in distant parts, it would be difficult to bring them together, and it might be of value to mix the paraplegic who was fit but had no home to go to with people with other disabilities. There had been a Scottish report on the Young Chronic Sick, which was a very usefuil document and was being discussed and which paid particular attention to the question of hospital care and environmental facilities. Here, Mr. Kerr corrected this statement by saying that the report did not pay particular attention to environment, as in fact there were only I 8 lines on environment, and they in the Scottish Council of Social Services were trying to stress that the environmental factors were very important indeed.

Agerholm, M. (England) wished to add her own particular interest which was one not only of domestic housing, which was obviously very important and now she thoughtaccepted in Great Britain, but also of insisting that all future public buildings or any modifications made to public buildings in the future should be accessible to the disabled. By public buildings, she meant not only just post offices, town hall and public libraries but also schools, universities or places where people were employed. She felt sure they must all have had the problem of getting people back to work-getting them suitably housed provided with transport to get them to and from work-but there was not a building in the neighbourhood they could get into with suitable facilities. This meant not only must they have a landscape entrance to works buildings or schools but the toilet and canteen facilities must be suitable. She thought that in America there was a university especially adapted for the disabled which was an enormous opportunity for people who need to add to their education. If they were to go around Great Britain and imagine themselves disabled they would know what a lot of unnecessary hazards and architectural barriers were put into new buildings being erected, and she thought it was the function of anyone interested in rehabilitation to publicise very widely the need and importance of making all public buildings in addition to domestic buildings suitable for the disabled. Increasing old age gave an added justification for this and she thought that this, as well as being able to get in and out of houses and by transport on the road had to be emphasized. Fortunately, all buildings suitable for the disabled were extremely suitable for the able-bodied.

Masse, $P$. (France) asked Dr. Damanski if he really thought there were no paraplegics in the first decade of life, because they had had some patients with traumatic paraplegia in the first decade of life and also they had had patients with spina bifida which was very near to the problem of traumatic paraplegia.

Damanski, $M$. (England) replied that they had not had a single request for the admission of a paraplegic patient below the age of Io, but he had been talking only of traumatic paraplegia and had not been referring to spina bifida or any other neurological disease. He understood from Dr. Hardy that he had had in his experience a few patients below the age of Io but at Southport they had not had a single case.

Walsh, F. (England): At Stoke Mandeville, they had had children with traumatic paraplegia and it was interesting that a number of those developed their paraplegia as a 
secondary vascular incident following the injury. One other point: Dr. Masse in Dr. Maury's interesting and very practical paper said how relatively few of his patients were able to dress themselves at home and had even stressed that a number of these patients could do this in hospital. Dr. Walsh thought this pointed to a weakness in the whole set-up, that there was not a close liaison (a) with the family of the paraplegic, either directly by coming down to the hospital (at Stoke Mandeville they tried to do this) or (b) by sending somebody out on a domiciliary visit. He understood that in Edenhall Hospital (Scotland) they were just starting this and that they had somebody who went out to the patient's home to help out with various snags. It might well be that the patient's independence at home would be helped if there were a closer liaision.

Guttmann, L. (England): With regard to paraplegics below the age of Io, at Stoke Mandeville they had admitted quite a number of children immediately after the war, the youngest being two years old. Those were traumatic paraplegics, as Dr. Walsh had mentioned, but they had also admitted paraplegics from other causes, in particular spina bifida, and in 1959 at a meeting of the Paediatric Section of the Royal Society of Medicine he had reported about 60 spina bifida children. This was a very important problem indeed, because if the Spinal Units could be enlarged to admit children below the age of Io many of the complications which developed in these unfortunate youngsters could be avoided. At Stoke Mandeville, with the help of the Ministry of Education, they had set up their own school where education of the children was included in their programme. Children came from all over the country and he would just like to mention a young bcy who came from Scotland with a spina bifida at the age of 2: that child was really a vegetable - he could not stand or sit and was incontinent of bladder and bowels. The boy had now been with them over $2 \frac{1}{2}$ years, was now walking, continent and going to school. That was just one example. They had received $£ 35,000$ from a private fund for enlarging their Children's Annexe, which would give them more facilities. This brought him to a question he would like to ask Dr. Damanski, who had quite rightly emphasised that hostels such as the one they were building at Stoke Mandeville should also be built in the North: what steps had he and his colleagues in Liverpool taken in this direction to convince and encourage the authorities to do so? In his memorandum to the Ministry he had emphasised the very point mentioned by Dr. Damanski, that these hostels should be set up in various parts of the country in the neighbourhood of a Spinal Unit. Unless doctors themselves approached the authorities concerned again and again with clear facts and stressed the need for early action nothing would be done.

Ross, F. C. (England), replying for Dr. Damanski, said that they had approached the Regional Board on many occasions on this subject and on the whole their attitude had been most sympathetic but they had been unable to do anything up to date owing to the question of finance. That was why he was particularly pleased to hear from Dr. Guttmann that the Ministry had accepted the principle of these additional units and having accepted this principle they would not be able to refuse finance to the Regional Boards, so there was certainly much more hope for the future.

Michaelis, L. S. (England) felt he should emphasise the needs of one particular group which Dr. Damanski could not mention because he did not have this group in his centre: that was the cervical lesion in old women, as opposed to men. He noticed that Dr. Damanski had had about 2I cervical men over the age of 60. The fact was that socially if not financially it was much worse for a family if the woman in the household were injured rather than the man. Elderly women who had fallen downstairs in their own homes arrived in the centre immediately after their accident, were looked after properly and were discharged in a perfectly fit though neurologically unaltered condition. They could not be looked after at home because there was no woman in the house and their elderly husbands could not look after them. This group was at the moment in the worst position of all. He hoped very much that the hostels for which they were all waiting would help to alleviate the present unsatisfactory position whereby they had to discharge these patients to hospitals, geriatric or otherwise, where they would get pressure sores and die. 
Harris, $P$. (Scotland) asked if Dr. Guttmann, in relation to his paper, would comment on the place for artificial insemination in paraplegics.

Guttmann, L. (England) said that this was indeed an important problem which they had examined for some years. They had tried to use the Prostigmine test for artificial insemination in those cases who had had a good seminal count. The Prostigmine test enabled them immediately to find out whether the person was completely sterile or not, in order to use the semen for artificial insemination. To do this, they asked the wife to measure her temperature for two months at least before the injection was carried out on the critical day. So far, they had had no success, but one of his former assistants, Dr. Spira, had been more successful and had published a paper about his case in the Lancet eight years ago. Another point he would mention was the fact that one negative Prostigmin test did not mean that there was no hope for producing pregnancy. He could report a patient with a lesion below TII who, despite the fact that the test was negative, married and sired a child, and he understood that the wife was again pregnant. They had found courses of Potensan combined with Vitamin E and testosterone beneficial in some cases for improving fertility. It was also very important to impress on paraplegics to do exercises at home to maintain and improve their fitness.

Walsh, F. (England) said they had had altogether three alleged pregnancies. One, he was quite certain, was wishful thinking. The other claimed to have had an abortion after three months and this was supported by her doctor, but this was still not definite. The third was quite interesting in that at the time of the insemination the total count was less than one million with, as far as he could remember, 20 per cent. motility. She became pregnant and lost the baby at 7 months in hospital. The gynaecologist said that the child appeared to be quite a normal foetus. These were the only three cases they had had at Stoke Mandeville. 